\title{
SOME DAMAGES DiLEMMAS IN PRIVATE LAW
}

\section{David McLauchlan*}

It is universally accepted that, subject to various restrictions including remoteness and mitigation of damage, the purpose of damages for breach of civil obligations is to put the parties whose rights have been breached in the same position, so far as money can do so, as if their rights had been observed. This is commonly referred to as the overriding compensatory principle. Nevertheless, although the principle can be quite simply stated, its application in practice commonly provokes much judicial disagreement and academic controversy. In this article, Professor McLauchlan discusses some of the modern leading cases that arguably could or should have been decided differently. As the title of the article suggests, the cases can fairly be described as giving rise to damages dilemmas.

\section{INTRODUCTION}

During the past 20 years there have been many important developments in the law governing the award of damages for breach of contract, tort, and infringement of proprietary or other analogous rights. These include: the rejection of the rule that damages cannot be recovered for late payment of a debt; ${ }^{1}$ substantial modification of the rule that damages are not available for mental distress caused by a breach of contract; ${ }^{2}$ the adoption of an agreement-centred approach to remoteness of damage in contract under which a loss may be considered too remote even if it was of the type or kind that would have been within the reasonable contemplation of the parties as a not unlikely result of the breach; ${ }^{3}$ the recalibration of the law relating to liquidated damages clauses and penalties; ${ }^{4}$ the clarification of

* Professor of Law, Victoria University of Wellington | Te Herenga Waka; Professorial Fellow, The University of Melbourne; Honorary Professor, The University of Queensland.

1 Sempra Metals Ltd v Inland Revenue Commissioners [2007] UKHL 34, [2008] AC 561.

2 See for example Farley $v$ Skinner [2001] UKHL 49, [2002] 2 AC 732.

3 Transfield Shipping Inc v Mercator Shipping Inc (The Achilleas) [2008] UKHL 48, [2009] AC 61 (defendants will escape liability for foreseeable loss if it cannot reasonably be inferred that they accepted responsibility for that loss).

4 Cavendish Square Holding BV v Makdessi [2015] UKSC 67, [2016] AC 1172; Paciocco v Australia and New Zealand Banking Group Ltd [2016] HCA 28, (2016) 258 CLR 525; Wilaci Pty Ltd v Torchlight Fund No 1 
the theoretical basis and availability of so-called "licence fee" or "negotiating" damages; ${ }^{5}$ recognition of the availability of lost opportunity damages for tortious misrepresentation despite the wrongfully induced transaction being profitable (and hence, prima facie no loss suffered) if it is established that, but for the misrepresentation, the plaintiff would have made greater profits; ${ }^{6}$ refinement of the principles governing awards of damages for the tort of misuse of private information; ${ }^{7}$ and rejection of "the notion that 'vindicatory damages' are a species of damages that stands separately from compensatory damages" in the law of torts. ${ }^{8}$ In this article, however, I want to address some even more basic issues that regularly trouble the courts when determining the appropriate award of compensatory damages for breach of civil obligations.

It is well established that, subject to the restrictions of remoteness of damage, "legal" causation, mitigation, and the "scope of duty principle" in negligence cases, ${ }^{9}$ the purpose of damages for breach of civil obligations is to put the parties whose rights have been breached in the same position, so far as money can do so, as if their rights had been observed. ${ }^{10}$ This is often referred to, whether the claim is in tort ${ }^{11}$ or contract, ${ }^{12}$ as the "overriding compensatory principle". Applying this principle to actions in tort, where plaintiffs are claiming that the wrongful conduct caused them loss or damage, the object is to repair the harm done. Thus, subject to the restrictions mentioned above, plaintiffs are entitled to be put in the position they would have occupied if the wrongful conduct had not occurred. However,

LP [2017] NZCA 152, [2017] 3 NZLR 293; and 127 Hobson Street Ltd v Honey Bees Preschool Ltd [2020] NZSC 53, [2020] 1 NZLR 179.

5 One Step (Support) Ltd v Morris-Garner [2018] UKSC 20, [2019] AC 649. See generally Andrew Burrows Remedies for Torts, Breach of Contract, and Equitable Wrongs (4th ed, Oxford University Press, Oxford, 2019) at 321-332.

6 Clef Aquitaine SARL v Laporte Materials (Barrow) Ltd [2001] QB 488; and Yam Seng Pte Ltd v International Trade Corpn Ltd [2013] EWHC 111 (QB), [2013] 1 Lloyd's Rep 526.

7 See for example Gulati v MGN Ltd [2015] EWCA Civ 1291, [2017] QB 149; and JN Varuhas and NA Moreham (eds) Remedies for Breach of Privacy (Hart Publishing, Oxford, 2018).

8 Lewis v Australian Capital Territory [2020] HCA 26, (2020) 381 ALR 375 at [2] per Kiefel CJ and Keane J, a view expanded on at length by Edelman J at [153]-[176]. See also $R$ (Lumba) $v$ Secretary of State for the Home Department [2011] UKSC 12, [2012] 1 AC 245.

9 See South Australia Asset Management Corpn v York Montague Ltd [1997] AC 191; Manchester Building Society v Grant Thornton UK LLP [2021] UKSC 20, [2021] 3 WLR 81; and Meadows v Khan [2021] UKSC 21, [2021] 3 WLR 147.

10 Livingstone v Rawyards Coal Co (1880) 5 App Cas 25 (HL) at 35.

11 See for example Smith New Court Securities Ltd v Scrimgeour Vickers (Asset Management) Ltd [1997] AC 254 (HL) at 282 and Clef Aquitaine, above n 6, at 500.

12 See for example Golden Strait Corpn v Nippon Yusen Kubishika Kaisha (The Golden Victory) [2007] UKHL 12, [2007] 2 AC 353 at [35] and [37]; and Bunge SA v Nidera BV [2015] UKSC 43, [2015] 3 All ER 1082 at [20] and [52]. 
applying the principle to actions for breach of contract, the general rule is that the plaintiffs are entitled to be put in the position they would have occupied if the contract had been performed. Therefore, again subject to the restrictions mentioned, plaintiffs are entitled to recover in respect of their loss of bargain or, as we say nowadays, their expectation interest. Accordingly, the ordinary measure of damages is the difference between their actual position and their promised position, or, in the currently preferred terminology of some damages scholars, the difference between their "breach position" and their "non-breach position". ${ }^{13}$

Nevertheless, the actual implementation of the compensatory principle has often provoked much judicial disagreement and academic controversy. Indeed, as we will see, there may be legitimate differences of opinion as to what is proper compensation. What is a windfall to one judge or commentator may be seen by another as justified by the compensatory principle. Opinions continue to be divided 25 years after the House of Lords' well-known decision in Ruxley Electronics and Construction Ltd $v$ Forsyth (Ruxley) ${ }^{14}$ as to whether Mr Forsyth ought to have recovered the cost of reconstruction of his swimming pool. On other occasions, however, we see cases wending their way through the courts when the answer is, or at least ought to be, obvious if first principles of the law of damages are understood. A good example of the latter is provided by Tiuta International Ltd $v$ De Villiers Surveyors $L t d^{15}$ which required an appeal to the United Kingdom Supreme Court to correct an erroneous award. In this case the claimant lent nearly $£ 2.5 \mathrm{~m}$ to a property developer on the security of a charge over a partially completed residential development. The loan was made in reliance on a valuation, assumed to be non-negligent, by the defendant valuers. Several months later the claimant made a further loan of over $£ 3 \mathrm{~m}$, all but $£ 289,000$ of which was used to pay off the first loan. This loan was entered into in reliance on a negligent valuation of the development by the defendants and, but for that negligence, it would not have been made. When the developer defaulted, the claimant sought to recover from the valuers the full amount of the outstanding indebtedness less some $£ 2.1 \mathrm{~m}$ that the property was expected to realise on sale. There being no issues concerning the likes of remoteness or mitigation of damage, the case called for an application of the basic tort measure of damages requiring an assessment of the difference between the claimant's position if the wrongfully induced second loan had not been made and its actual position. On this basis, the claimant faced the insuperable difficulty that, although the second loan would not have been made and the first loan would have remained owing, that first loan would not have been repaid in any event. In principle,

13 This terminology originates in A Dyson and A Kramer "There is No 'Breach Date Rule': Mitigation, Difference in Value and Date of Assessment" (2014) LQR 259 at 261.

14 Ruxley Electronics and Construction Ltd v Forsyth [1996] 1 AC 344 (HL). Compare the almost equally contentious decisions to allow cost of cure or reinstatement damages in Tabcorp Holdings Ltd $v$ Bowen Investments Pty Ltd [2009] HCA 8, (2009) 236 CLR 272 and Marlborough District Council v Altimarloch Joint Venture Ltd [2012] NZSC 11, [2012] 2 NZLR 726.

15 Tiuta International Ltd v De Villiers Surveyors Ltd [2016] EWCA Civ 661, reversed [2017] UKSC 77, [2017] 1 WLR 4627. 
therefore, the claimant could only recover the amount of the new money, some $£ 289,000$, obtained under the second loan. Astonishingly, the net amount of the whole indebtedness was awarded by a majority of the Court of Appeal. However, the Supreme Court had no hesitation in allowing the valuers' appeal. As Lord Sumption, who delivered the judgment of the Court, correctly pointed out, the answer was "perfectly straightforward and turn[ed] on ordinary principles of the law of damages." 16

\section{AN ENCOUNTER WITH SIR ROBIN COOKE}

I have spent a good deal of my 51 years in academic life thinking and writing about issues in the law of damages. I was confident about my mastery of most important aspects of the subject until a memorable encounter with Sir Robin Cooke, as he then was, in Christchurch in 1993.

If there is one small thing that Sir Robin and I had in common, it was a fascination with issues of damages law. An early important contribution by him to the subject came in his 1978 Cambridge Law Journal article on remoteness of damage in contract and tort. ${ }^{17}$ One of the themes of that article, which was repeated 15 years later in his judgment when President of the Court of Appeal in McElroy Milne $v$ Commercial Electronics $L t d,{ }^{18}$ was that reasonable foresight or contemplation, while an important consideration, cannot be the sole determinant of whether consequential loss is recoverable for breach of contract. In his view, remoteness was a question of fact that could only be resolved after taking into account a range of other relevant considerations. This view was vindicated, at least so far as remoteness in contract is concerned, by the 2008 decision of the House of Lords in Transfield Shipping Inc v Mercator Shipping Inc (The Achilleas). ${ }^{19}$ In that case, a majority of their Lordships held that the orthodox textbook descriptions of the law of remoteness of damage in contract are no longer adequate. A loss may now be considered too remote even if it was of the type or kind that would have been within the reasonable contemplation of the parties as a likely or not unlikely result of the breach. Although satisfying that requirement will usually suffice, it will not always do so. Defendants will escape liability for foreseeable loss if it cannot reasonably be inferred that they accepted responsibility for that loss. In a subsequent article ${ }^{20} \mathrm{I}$ built open Sir Robin's discussion of the relevant factors that must be weighed in determining whether it is reasonable to infer such an assumption of responsibility, highlighting in particular the importance of whether there is a substantial disproportion between the foreseeable loss suffered by the plaintiffs and the consideration received by the defendants. My

16 Tiuta International Ltd v De Villiers Surveyors Ltd [2017] UKSC 77, [2017] 1 WLR 4627 at [6].

17 Sir Robin Cooke "Remoteness of Damages and Judicial Discretion" (1978) 37 CLJ 288.

18 McElroy Milne v Commercial Electronics Ltd [1993] 1 NZLR 39 (CA).

19 The Achilleas, above n 3.

20 D McLauchlan "Remoteness Re-invented?" (2009) 9 OUCLJ 109. 
analysis has since been endorsed in our leading textbook ${ }^{21}$ and it is to be hoped that our courts will do likewise when the opportunity arises. As Sir Robin pointed out, ${ }^{22}$ adoption of what might be called his "multi-factorial approach" to determining the outcome of remoteness issues may not "make the law any more certain, in the sense of making the results of cases more predictable" but it would enhance the transparency of the law by "bringing into a more direct light the kind of considerations which tend to sway decisions". Judgments would not suffer from what Lord Hoffmann, writing extrajudicially ${ }^{23}$ after his judgment in The Achilleas, has described as the "impoverishment of reasoning", 24 "the intellectual sleight of hand", ${ }^{25}$ the "invisible distinctions", ${ }^{26}$ and the reliance on "the meagre concepts of foreseeability and type of harm" 27 that characterise decisions in remoteness cases. ${ }^{28}$

Returning to my 1993 encounter with Sir Robin, it was memorable because it got me thinking more deeply about some of the intricacies and mysteries of the law of damages and influenced the direction of my research for a number of years. Sir Robin delivered the opening address at the annual Australasian Law Teachers Association Conference and after dinner on the first night, he approached me and a group of other academics and sought our advice on a "hypothetical" damages issue that was troubling him. I have to confess that it had me stumped! The situation was this. The defendant's sheep escaped and destroyed the plaintiff's squash crop that was destined for export. The defendant was therefore prima facie liable to pay damages for the tort of "cattle" trespass. But what, Robin said, if the plaintiff would never have been paid by the export company that had entered into a forward contract to purchase the crop due to the company's insolvency? Could it be said that the plaintiff had not suffered a loss in these circumstances? Or were damages to be assessed at the date of the trespass so that subsequent events were irrelevant? If so, the plaintiff should recover the market value of the crop if it had not been destroyed, not the price payable by the export company because that would never have been paid. I am not sure that the discussion was helpful to Robin, but this was the outcome of the case that he was grappling with at the time. Two months later the Court of Appeal unanimously

21 J Burrows, J Finn and M Barber Burrows, Finn and Todd on the Law of Contract in New Zealand (6th ed, LexisNexis, Wellington, 2018) at 848.

22 Cooke, above n 17, at 300.

23 Lord Hoffmann "The Achilleas: Custom and Practice or Foreseeability?" (2010) 14 Edinburgh L Rev 47 at 55 .

24 At 53

25 At 54 .

26 At 58

27 At 57 .

28 Nevertheless, it must be said that this whole area, and in particular the impact of The Achilleas, remains contentious in the United Kingdom. See J Edelman McGregor on Damages (20th ed, Sweet \& Maxwell, London, 2018) at 8.168-8.181. 
overturned the High Court's decision that no loss had been suffered. As it transpired, the case ${ }^{29}$ was not quite as difficult as Robin's "hypothetical" suggested because his judgment recorded that the export company was in financial difficulties at the time the crop was damaged and that, if the trespass had not occurred, the plaintiff might well have cancelled the contract and therefore been able to realise the crop at market value. Nevertheless, as I mentioned earlier, the case and the earlier discussion with Robin got me thinking about some fundamental issues of damages law. For example, might damages be recoverable for "loss" in some circumstances despite the fact that an award would put the plaintiff in a better position than if the tort or breach of contract had not occurred? Also, to what extent are subsequent external events that might appear to reduce or eliminate the loss claimed, or subsequent actions to like effect by the claimant, to be brought into account? These and similar issues have long caused difficulties for the courts and commentators. I want to highlight some of the most contentious modern cases, starting with the decision of the English Court of Appeal in Bence Graphics International Ltd $v$ Fasson UK Ltd. ${ }^{30}$

\section{BENCE GRAPHICS INTERNATIONAL V FASSON}

Here the plaintiffs bought a large quantity of vinyl film from the defendants which they used in the manufacture of labels for identifying shipping containers. The film was defective. It did not have the durability of at least five years as warranted by the defendants. Complaints were made by the end users, but these resulted in only one relatively minor claim for compensation that was duly settled by the plaintiffs and reimbursed by the defendants. The plaintiffs sought to recover the whole purchase price of some $£ 564,000$. They invoked the normal measure of damages for breach of warranty of quality as codified in s 53(3) of the Sale of Goods Act 1979. They succeeded at first instance, with the Judge ruling that the film actually delivered was worthless. However, the Court of Appeal, by a majority, allowed the defendants' appeal. They refused to follow the well-known decision of the same Court in Slater v Hoyle \& Smith Ltd ${ }^{31}$ that supported the plaintiffs' claim because it was wrong "to award a buyer more than the evidence clearly showed he had lost". ${ }^{32}$

In my view, although some of the reasoning was questionable, this was the correct result. Nevertheless, the decision has been severely criticised by leading commentators. ${ }^{33}$ The late Professor

29 Gardiner v Metcalf [1994] NZLR 8 (CA).

30 Bence Graphics International Ltd v Fasson UK Ltd [1998] QB 87.

31 Slater v Hoyle \& Smith Ltd [1920] 2 KB 11.

32 At 105 per Auld LJ.

33 See for example GH Treitel "Damages for Breach of Warranty of Quality" (1997) 113 LQR 188; M Bridge "Defective Goods and Sub-sales" [1998] JBL 259 at 262; "Markets and Damages in Sale of Goods Cases" (2016) 132 LQR 405; and R Stevens "Damages and the Right to Performance: A Golden Victory or Not?" in JW Neyers, R Bronaugh and S Pitel (eds) Exploring Contract Law (Hart Publishing, Oxford, 2009) 171 at 179-180 ("Bence is wrong in reasoning and result"). Compare, however, the support for Bence in Burrows, above $\mathrm{n} 5$, at 194. On the other hand, see the endorsement of Treitel's criticisms by Flaux J in OMV Petrom 
Treitel argued that the plaintiffs did suffer a loss that was not avoided through receipt of the gains from the sale of the labels. Those gains were purely accidental and need not be brought into account. After all, the plaintiffs might have chosen to use goods bought from other suppliers in their manufacturing process in which case damages based on the difference between actual and warranted values of what the defendants supplied would clearly have been payable. The plaintiffs' good fortune in not receiving claims from their buyers was not a good reason for reducing their damages.

I disagree. Of course the defendants too could count themselves lucky that the defect in the goods they supplied was not discovered until long after those goods were incorporated into the manufactured product and that most of the end users of the product did not seek legal redress. But one might ask, why should that be relevant when the goal is compensation? Upholding the plaintiffs' damages claim smacks of punishment rather than compensation. Damages should be awarded on the basis of what actually happened, not on the basis of what might have happened on worst-case scenarios from the defendants' point of view.

Interestingly, the result in Bence has been justified on the technical basis that the defect in the goods was latent. ${ }^{34}$ In such cases, principles of mitigation, which provide the foundation for the normal assumption that where there is an available market damages are to assessed at the date of breach, is not engaged. ${ }^{35}$ The plaintiffs cannot have behaved unreasonably by failing to resort to the market to buy replacement vinyl because that presupposes that they had a choice to do so. In such cases, so the argument goes, the court's task is to determine the plaintiffs' actual loss which was minimal, certainly nowhere near $£ 564,000$.

However, this argument, while seemingly sound in principle, does not solve my dilemma. Let us suppose that the defect in Bence had been patent and therefore the plaintiffs were aware of the need to resort to the market. Nevertheless, they decided to use the defendants' vinyl instead. According to the argument I am discussing, mitigation principles require the damages to be assessed as if the plaintiffs had resorted to the market upon discovering the breach, even though they did not in fact do so. This is because they had a free choice in the matter. Their claim now succeeds in full. Intuitively, this seems wrong. Here the plaintiffs deliberately assume the risk of complaints and damages claims

SA v Glencore International AG [2015] EWHC 666 (Comm) at [187]-[197]. Flaux J's decision to award the claimant damages of over USD40m for the tort of deceit in respect of the defendant's fraudulent misrepresentation of several cargos of oil was affirmed by the Court if Appeal ([2016] EWCA Civ 778, [2016] 2 Lloyd's Rep 432), but the Court, while disposed to prefer Slater v Hoyle \& Smith Ltd over Bence, decided that it was unnecessary to resolve this "controversy" because the claim was in tort (at [46]). Perhaps more interesting is that the large award has been convincingly criticised by A Summers and A Kramer "Deceit, Difference in Value and Date of Assessment" (2017) 133 LQR 41. The authors conclude (at 46) that the claimant should have "recovered no damages at all"!

34 See Dyson and Kramer, above n 13, at 275; and A Kramer The Law of Contract Damages (2nd ed, Hart Publishing, Oxford, 2017) at 4-99.

35 See Dyson and Kramer, above n 13, and the authorities discussed therein. 
by their customers. Yet, when few if any such claims materialise, it seems they can still get back all the money they paid to the defendants by way of a damages award.

The decision in Bence was followed by the New Zealand High Court in the interesting case of McSherry v Coopers Creek Vineyard Ltd. ${ }^{36}$ Again the facts were very simple. A wine producer and wholesaler sold bottles of wine to a retail wine merchant. The wine was mislabelled. Its quality was inferior to that stated on the labels. The buyer onsold all of the wine on his normal terms to retail customers. None of it was returned. Nevertheless, the buyer claimed damages of $\$ 23,000$, the alleged difference between the value of the wine the seller agreed to supply and the value of the wine actually supplied. Panckhurst $\mathrm{J}$ rejected the claim on the ground that it would "subvert, not promote, the purpose of damages in contract". ${ }^{37}$ His Honour reviewed the criticisms of Bence but was not persuaded by them because the "overarching principle" was that "damages for breach of contract are designed to place the innocent party in the same position he would have been in if the contract had been performed." ${ }^{38}$ Instead of the damages claimed restoring the buyer's position, it would have elevated his position "on the basis of a theoretical loss". ${ }^{39}$ This decision too has not escaped criticism ${ }^{40}$ but, in my view, the Judge was correct. It would have been a nonsense on the particular facts to award substantial damages for financial loss to a plaintiff who was already in exactly the same financial position as if the contract had been performed.

\section{THE GOLDEN VICTORY}

Similar difficulties concerning the application of the compensatory principle have arisen in several decisions of the House of Lords and its successor, the Supreme Court, over the past 15 years. Let us start with the most controversial of them all, the decision of the House of Lords in Golden Strait Corpn v Nippon Yusen Kubishika Kaisha (The Golden Victory). ${ }^{41}$ Although the compensatory principle was variously described as "the governing principle in contract", ${ }^{42}$ "fundamental", ${ }^{43}$ "overriding", 44 and "clear" 45 and it was accepted that "[t]he basic facts of this case could hardly be

36 McSherry v Coopers Creek Vineyard Ltd (2005) 8 NZBLC 101,619.

37 At [20].

38 At [17].

39 At [20]

40 See C Hawes "Damages for Defective Goods" (2005) 121 LQR 389; and "Sale of Goods Contracts: The Effect of Subcontracts on Damages for Breach of Warranty of Quality" (2005) 11 NZBLQ 253.

41 Golden Strait Corpn v Nippon Yusen Kubishika Kaisha [2007] UKHL 12, [2007] 2 AC 353.

42 At [9] per Lord Bingham.

43 At [29] per Lord Scott and [83] per Lord Brown.

44 At [35] and [37] per Lord Scott.

45 At [38]. 
simpler", ${ }^{46}$ their Lordships were divided 3:2 as to the correct outcome. The majority ruled that the plaintiff's claim offended the compensatory principle, but the minority were adamant that the claim was perfectly consistent with it. What happened was that charterers of the vessel Golden Victory wrongfully repudiated the charter three years into its seven-year term. The owners accepted the repudiation and claimed damages according to the normal measure of the difference between the charter rate and the market rate for the remaining four years of the term. There would have been no doubt as to their entitlement to such recovery but for three further facts. First, the contract contained a "war clause" giving each party the right to cancel the charter if war broke out between any two or more of several countries including the United States, the United Kingdom and Iraq. Secondly, in March 2003, some 14 months after the repudiation, the Second Gulf War commenced. Thirdly, the arbitrator found that the charterers would have cancelled the charter had it remained on foot because they were "fundamentally disenchanted" with it. In these circumstances, the Court of Appeal upheld the trial Judge's ruling that, although at the time of the repudiation war would have been considered a mere possibility, damages were to be measured by taking into account that the owners would only have had the benefit of the charter until the outbreak of the war.

The House of Lords agreed despite powerful dissents from two renowned commercial judges, Lord Bingham and Lord Walker. The majority ${ }^{47}$ held that allowing the owners' claim in respect of the whole of the four-year period after the repudiation "would be inconsistent with the overriding compensatory principle on which awards of contractual damages ought to be based". ${ }^{48}$ Since the contract would have been brought to an end pursuant to the war clause within 14 months, it followed that "in principle, the owners ... are not entitled to any damages in respect of the period thereafter."49 The minority, on the other hand, accepted the owners' argument that the damages should be assessed when the contract was brought to an end and the owners could reasonably be expected to enter the market to find a substitute charterer so that "[e]vents occurring later, not affecting the value of the contractual right which the owner has lost at that time, are irrelevant." ${ }^{50}$ In their view, the decision of the Court of Appeal "undermine[d] the quality of certainty which is a traditional strength and major selling point of English commercial law, and involve[d] an unfortunate departure from principle." 51

\author{
46 At [69] per Lord Brown. \\ 47 Lord Scott, Lord Carswell and Lord Brown. \\ 48 At [35] per Lord Scott. \\ 49 At [37]. \\ 50 At [1] per Lord Bingham. \\ 51 At [1] per Lord Bingham.
}


It would be inappropriate to traverse in this article the many arguments for and against the majority's decision. Suffice it to say that the opinion of commentors is divided ${ }^{52}$ and that I have changed my mind on several occasions. My initial reaction was to favour the view of the minority. Why, I thought, should the charterers be allowed to rely on a clause that was premised on the charter remaining on foot and being duly performed up until the time of its being invoked? And I am still inclined to think that the only basis for reducing recovery in the circumstances before the Court would be a finding that a substitute charterer would also have cancelled pursuant to the war clause. Two members of the majority appear to have thought that this was the case, but no explanation was given. It was simply asserted that "it can be assumed that the hypothetical substitute charterers would similarly have cancelled their contract on the outbreak of the War." 53 This is contrary to my understanding that charters are by no means invariably cancelled by charterers upon the outbreak of war between designated countries, particularly since market rates will likely have risen. ${ }^{54}$

Be all that as it may, it can now be safely said that United Kingdom law is settled because the decision in The Golden Victory has been unanimously endorsed by the Supreme Court in Bunge SA v Nidera $B V .{ }^{55}$ In that case, the buyers of Russian wheat claimed damages of USD3m when the sellers wrongfully repudiated the contract. The claim failed because the Russian Government banned the export of wheat during the delivery period and the contract provided that, in the event of such a ban, the contract was cancelled. As it transpired, therefore, the buyers would not have been able to enforce the contract and no loss was recoverable. Two interesting points arise out of the judgments. First, the approval of The Golden Victory was based on the problematic assumption I have mentioned that the hypothetical substitute charter would also have been cancelled on the outbreak of the Gulf war. ${ }^{56}$ Secondly, it was accepted that relevant subsequent events that may reduce or eliminate loss were not confined to situations where the defendant would have been relieved of the obligation to perform under the express terms of the contract but extended to situations where the plaintiff would have been

52 See for example GH Treitel "Assessment of Damages for Wrongful Repudiation" (2007) 123 LQR 9; M Mustill "The Golden Victory - Some Reflections" (2008) 124 LQR 569; F Reynolds "The Golden Victory A Misguided Decision" (2008) 38 HKLJ 333; and V Goldberg "After The Golden Victory: Still Lost at Sea" (2016) 22 Journal of International Maritime Law 111. But compare the contrary views of, for example JW Carter and E Peden "Damages Following Termination for Repudiation: Taking Account of Later Events" (2008) 24 JCL 145; S Harder "The Exculpation of Repudiating Parties by a Right to Terminate the Contract" [2009] JBL 679; and R Stevens, above n 33, at 195-197.

53 Golden Strait Corpn v Nippon Yusen Kubishika Kaisha, above n 41, at [82] per Lord Brown, with whom Lord Carswell agreed.

54 According to the Case for the Appellants in the House of Lords (at [75]), counsel argued that there was no basis for a presumption that the substitute charterers or the owners would have cancelled upon the outbreak of war. I also understand that the charterers in the present case had several other charters that were not cancelled.

55 Bunge SA v Nidera BV [2015] UKSC 43, [2015] 3 All ER 1082.

56 At [21]-[22]. 
unable to perform when the time for performance arrived. ${ }^{57}$ This conclusion had in fact been reached some 18 months earlier in a High Court case that was not cited to their Lordships. ${ }^{58}$ On the assumption that The Golden Victory was rightly decided, that extension seemed pretty obvious to me but it was trenchantly criticised by Professor Treitel. ${ }^{59} \mathrm{He}$ argued that the two situations are fundamentally different, but in my view, the case for reducing or eliminating the damages is at least equally as strong in the scenario where subsequent events show that the plaintiff would have breached the contract as it is when such events show that the defendant could and would have invoked an express cancellation clause.

There is no need to debate this and related issues here because I have discussed them elsewhere. ${ }^{60}$ Instead I prefer to discuss three later decisions of the United Kingdom Supreme Court on the law of damages, each of which is highly contentious: Hughes-Holland v BPE Solicitors, ${ }^{61}$ Swynson Ltd v Lowick Rose LLP 62 and Fulton Shipping Inc of Panama $v$ Globalia Business Travel SAU (The New Flamenco). ${ }^{63}$

\section{$V$ HUGHES-HOLLAND V BPE SOLICITORS}

This case was described by Lord Sumption as giving rise to "one of the main dilemmas in the law of damages". ${ }^{64}$ It is a decision that to my mind illustrates the unsatisfactory state of the law relating to the measure of damages for professional negligence. Essentially what happened was that the defendant solicitors negligently misrepresented that the $£ 200,000$ their client was proposing to invest in the development of a commercial building would be used to fund the development work when in fact it was to be used to pay off the developer's debts. The client would never have advanced the money if he had known this. The development never proceeded and the client lost nearly all of his advance. ${ }^{65}$ Crucially, however, it was found that, even if the advance had been used for the purpose the client intended, it would not have been recovered. The whole project was unviable. In these

57 At [16] and [23].

58 Flame SA v Glory Wealth Shipping PTE Ltd (The Glory Wealth) [2013] EWHC 3153 (Comm), [2013] 2 Lloyd's Rep 653.

59 In MG Bridge (ed) Benjamin's Sale of Goods (9th ed, Sweet \& Maxwell, London, 2014) at [19.171]-[19.182].

60 D McLauchlan "Repudiatory Breach, Prospective Inability, and The Golden Victory" [2015] JBL 530.

61 Hughes-Holland v BPE Solicitors [2017] UKSC 21, [2018] AC 599.

62 Swynson Ltd v Lowick Rose LLP [2017] UKSC 32, [2018] AC 313.

63 Fulton Shipping Inc of Panama v Globalia Business Travel SAU [2017] UKSC 43, [2017] 1 WLR 2581 [The New Flamenco (SC)].

64 Hughes-Holland v BPE Solicitors, above n 61, at [1].

65 In fact, he was later adjudicated bankrupt and it was his trustee in bankruptcy who pursued the appeal to the Supreme Court. 
circumstances, the Supreme Court held that the solicitors were not liable because the negligent provider of information is only liable for the consequences of the information being incorrect. Here no damages were recoverable because, even if the representation had been true, the advance would have been lost. In so ruling, the Court applied the much debated and often criticised "SAAMCO principle" first laid down by Lord Hoffmann in South Australia Asset Management Corpn v York Montague $L t d^{66}$ and endorsed by their Lordships on other occasions. ${ }^{67}$ These cases held that the scope of the duty of care owed by a valuer to a lender did not extend to protecting the lender against a loss that would have been a consequence of the transaction even if the representation had been true. In my view, ${ }^{68}$ and the view of other commentators, ${ }^{69}$ the principle is flawed. The most basic of the many objections to the principle is that it wrongly focuses on the consequences of the information supplied being incorrect and therefore measures damages by reference to the claimant's position had that information been correct. Whereas the essence of the victim's complaint in the usual case of negligent misrepresentation is that he or she was wrongfully induced to enter into a transaction that would not otherwise have been entered into. Accordingly, the aim of the damages award should be to put the claimant in the position he or she would have occupied if the transaction had not gone ahead. It should be irrelevant that the transaction would have been a losing one. The question is: what loss flowed from the alteration of the claimant's position in reliance on the defendant's careless misrepresentation? Surely if I am induced to purchase a property by my solicitor's careless misrepresentation concerning matters affecting my ability to develop the property, and I would not have gone ahead if the correct information had been given, I should be able to recover the difference between the high price I paid and the true market value of the property. This should be so regardless of whether, even if the correct information had been given, other obstacles would have prevented a successful development. Indeed, it is not clear to me why the English courts should be so anxious to limit the liability of negligent solicitors and other professional advisers who are usually fully insured and thus leave their clients substantially out of pocket. Needless to say, I hope that if similar facts to those in Hughes-Holland arose in New Zealand a different conclusion would be reached. I suspect, however, that the United Kingdom Supreme Court's reaffirmation and refinement of the SAAMCO principle earlier this year in Manchester Building Society $v$ Grant Thornton $U K L L P^{70}$ and Meadows $v$ Khan, ${ }^{71}$ albeit that it is

66 South Australia Asset Management Corpn v York Montague Ltd, above n 9.

67 See for example Nykredit Mortgage Bank plc v Edward Erdman Group Ltd (No 2) [1997] 1 WLR 1627 (HL); and Platform Home Loans Ltd v Oyston Shipways Ltd [2000] 2 AC 190 (HL).

68 See D McLauchlan "A Damages Dilemma" (1997) 12 JCL 114.

69 See for example Burrows, above n 5, at 117-127. The author concludes (at 126) that:

[i]t is not clear why Lord Hoffmann, followed by Lord Sumption in the BPE case, should wish to protect professionals from the full consequences of their provision of incorrect information.

70 Manchester Building Society v Grant Thornton UK LLP, above n 9.

71 Meadows $v$ Khan, above n 9. 
renamed the "scope of duty" principle, diminishes the chances of this happening. ${ }^{72}$ None of the three judgments indicates the slightest reservation about the outcome in Hughes-Holland.

\section{SWYNSON AND THE NEW FLAMENCO}

The other two cases of Swynson and The New Flamenco involved successful appeals from decisions of the Court of Appeal. The facts of the cases were very different but they did raise a broadly similar issue as to whether the "loss" in respect of which damages were claimed had been avoided: in Swynson, by the post-breach conduct of a third party and in The New Flamenco, by the post-breach conduct of the claimants themselves.

The decisions of the Court of Appeal ${ }^{73}$ were the primary focus of a joint presentation on aspects of the law of damages by the President of the New Zealand Court of Appeal, Stephen Kos, and me to the Australasian Appellate Judges Conference in Melbourne in October 2016, which was about a month before the Supreme Court hearing. Stephen discussed the decision in Swynson and he concluded by suggesting that the appeal was unlikely to succeed. I discussed The New Flamenco and suggested that the appeal in that case would succeed. At the end of the session we were approached by Justice Helen Winkelmann and told that we were both wrong! She was firmly of the opinion that Swynson was wrongly decided and The New Flamenco rightly decided. The upshot was that Stephen and I had to buy Helen lunch if she was correct. As it transpired, only my prediction was correct, so the lunch date enabling one of their Honours to gloat never took place! I have to confess, however, that at the time I agreed with Stephen's prediction and I suspect that he would still contend that the appeal in Swynson ought not to have been allowed.

The essential facts for present purposes were as follows. In 2006 Swynson, a company controlled and owned by a Mr Hunt, lent $£ 15 \mathrm{~m}$ to EMSL to enable a management buy-out of an American company, Evo. The loan was made in reliance on a negligent due diligence report prepared by the accountancy firm of Hurst Morrison Thomson (HMT) who subsequently changed their name to Lowick Rose LLP. The report failed to disclose some serious problems concerning Evo's finances, most importantly, the insufficiency of its working capital. If the true position had been reported, the transaction would not have gone ahead. In 2007 Evo began to suffer cash-flow problems that necessitated a further loan by Swynson to EMSL of $£ 1.75 \mathrm{~m}$. However, Evo's finances continued to deteriorate and in June $2008 \mathrm{Mr}$ Hunt agreed to make another loan to EMSL through Swynson of $£ 3 \mathrm{~m}$. As part of this transaction, Mr Hunt obtained an 85 per cent shareholding in EMSL.

72 On the other hand, it should be noted that the SAAMCO principle was rejected by the High Court of Australia in Kenny \& Good Pty Ltd v MGICA (1992) Ltd (1999) 199 CLR 413 (see D McLauchlan and C Rickett "SAAMCO in the High Court of Australia" (2000) $116 \mathrm{LQR} 1$ ) and that the principle is yet to be the subject of a full-scale consideration in New Zealand.

73 Swynson Ltd v Lowick Rose LLP [2015] EWCA Civ 629, [2016] 1 WLR 1045; and Fulton Shipping Inc of Panama v Globalia Business Travel SAU [2015] EWCA Civ 1299, [2016] 1 WLR 2450 [The New Flamenco (CA)]. 
Nevertheless, despite these cash injections, Evo's performance did not improve. In December 2008 Mr Hunt made a fateful decision to refinance the 2006 and 2007 loans. He personally lent over $£ 18 \mathrm{~m}$ to EMSL on the condition that it be used to repay the latter loans. The loans were duly repaid and as a result, only the June 2008 loan was left owing to Swynson. There were two main reasons for this transaction. First, under United Kingdom law once Mr Hunt acquired control of both Swynson and EMSL, Swynson became liable to pay tax on interest payable by EMSL even though payments were not being made. Secondly, Mr Hunt decided that it was contrary to Swynson's best interests for the impaired loans to remain on its books. No consideration was given to the possibility that the refinancing might jeopardise a future damages claim against HMT.

Despite Mr Hunt's best efforts, Evo's fortunes did not improve and eventually the company was wound up. Neither the June 2008 loan nor the refinancing of the earlier loans were repaid and in 2012 Swynson issued proceedings against $\mathrm{HMT}^{74}$ claiming damages of over $£ 16 \mathrm{~m}$ (representing the amount of the loans less the sums received from various realisations). HMT did not dispute that they were liable for the amount of the 2008 loan but contended that no damages were recoverable by Swynson in respect of the earlier loans because they had been repaid by EMSL and accordingly, there was no loss suffered.

However, the trial judge, Mrs Justice Rose, held that the refinancing was res inter alios acta, that is, a collateral transaction that did not go to reduce the damages recoverable from the accountants. A majority of the Court of Appeal agreed. ${ }^{75}$ The legal position should be no different than if Mr Hunt had made a gift to Swynson of the amount outstanding under the loans to enable Swynson to balance its books. To hold otherwise "would be a triumph of form over substance"76 and fail to have regard to "the realities of the case". ${ }^{77}$ The fact that Mr Hunt chose for tax reasons to advance funds to the borrower to enable repayment of the loans, rather than directly to Swynson, was not something that affect[ed] the substantive position or the just result as between Swynson, the accountants and $\mathrm{Mr}$ Hunt. The situation was analogous to the case of benevolent payments where, on the basis of established House of Lords' authority, ${ }^{78}$ considerations of "justice, reasonableness and public policy" dictate that the benefit need not be brought into account. To hold otherwise "would be contrary to 'the ordinary man's sense of justice, and therefore contrary to public policy'". ${ }^{79}$

$74 \mathrm{Mr}$ Hunt also joined the proceedings but a discussion of his ultimately unsuccessful claims is beyond the scope of this article.

75 Swynson Ltd v Lowick Rose LLP (CA), above n 73, per Longmore and Sales LJJ, Davis LJ dissenting.

76 At [16] per Longmore LJ.

77 At [18]. See also Sales LJ at [53]-[54].

78 Parry v Cleaver [1970] AC 1 at 13.

79 Swynson Ltd v Lowick Rose LLP (CA), above n 73, at [56] per Sales LJ, quoting from the judgment of Lord Reid in Parry v Cleaver, above n 78, at 14. 
The Supreme Court was unanimous in allowing the accountants' appeal. Indeed, one only had to read the first paragraph of Lord Sumption's lead judgment to know the result. His Lordship said: ${ }^{80}$

The distinct legal personality of companies has been a fundamental feature of English commercial law for

a century and a half, but that has never stopped businessmen from treating their companies as indistinguishable from themselves. Mr Michael Hunt is not the first businessman to make that mistake, and doubtless he will not be the last.

The repayment of the loans "discharged the very liability whose existence represented Swynson's loss" and therefore "could not possibly be regarded as collateral." 81 It could not be treated as discharging the loans as between Swynson and the borrower, but not as between Swynson and the accountants. The fact that the likes of charitable payments, pensions and insurance proceeds need not be brought into account due to considerations of "justice, reasonableness and public policy" was not to be "treated by judges as a green light for doing whatever seems fair on the facts of the particular case." 82 Furthermore, the fact that the position would have been different if Mr Hunt had given the amount of the loans to Swynson did not mean, as the Court of Appeal majority said, that a ruling in favour of the accountants would represent a triumph of form over substance. Such a gratuitous payment was different in nature from what occurred in the present case because Mr Hunt's personal loan to the borrower was intended to and did lead to actual repayment of the relevant loans that Swynson had made. The fact that the transaction could have been differently arranged did not mean that it must have the same consequences as if it had been differently arranged. In summary, Swynson's damages claim in respect of the 2006 and 2007 loans had to fail because Mr Hunt and Swynson were separate legal persons, the repayment of the loans discharged the borrower's liability to Swynson, and therefore Swynson could not be said to have suffered a loss as a result of having been induced by negligence to make those loans.

The question can fairly be asked, however, whether the law was so clear that Swynson's case was hopeless. Obviously, three experienced lower court judges thought not. Furthermore, their desire to reach what they perceived to be the just result despite the technical obstacles was not without precedent in recent case law. There have been several modern cases in which the courts have allowed claims, or rejected defences, on the basis that to hold otherwise would represent a triumph of form over substance. One notable example, albeit itself contentious, is Shell UK Ltd v Total UK Ltd ${ }^{83}$ where

80 Swynson Ltd v Lowick Rose LLP (SC), above n 62, at [1].

81 At [13] per Lord Sumption.

82 At [98] per Lord Neuberger. See also Lord Sumption (at [11]):

Justice, reasonableness and public policy are ... the basis on which the law has arrived at the relevant principles. They are not a licence for discarding those principles and deciding each case on what may be regarded as its broader commercial merits.

83 Shell UK Ltd v Total UK Ltd [2010] EWCA Civ 180, [2011] QB 86. 
the Court of Appeal held that a duty of care was owed to a beneficial owner of property by a defendant whose negligent actions damaged the property because "it would be a triumph of form over substance to deny a remedy to the beneficial owner ... when the legal owner is a bare trustee for that beneficial owner." ${ }^{84}$ Another example, also contentious, is Menelaou $v$ Bank of Cyprus Plc ${ }^{85}$ where the Supreme Court rejected the defence to the bank's unjust enrichment claim because, inter alia, it "represent[ed] a triumph of form over substance, or, to use the words of Lord Steyn in Banque Financière [1999] 1 AC $221,227 \mathrm{C}$, 'pure formalism."' 86 I believe that the question can fairly be asked whether their Lordships were correct to disavow such an approach in Swynson.

Let us turn now to the Supreme Court's decision in The New Flamenco. The basic facts were more straightforward. The defendant charterers repudiated the time charter of a small cruise ship owned by the claimants when the charter still had two years to run. The owners accepted the repudiation and, since there was no possibility of arranging a substitute two-year time charter in the market, they decided to sell the ship. The price obtained was USD23,765,000. The owners subsequently sued to recover the net loss of profits they would have earned (some $€ 7.5 \mathrm{~m}$ ) if the charter had not been repudiated. However, since the value of the ship when the charter was due to end would have been a mere USD7,000,000 as a result of a fall in the charter market, the charterers argued that the difference of USD16,765,000 between this sum and the actual sale price must be brought into account. Accordingly, no damages should be awarded because the sum exceeded the lost profits claimed. The arbitrator agreed. He ruled that the "benefit" should be brought into account since the sale was caused by the breach and was a reasonable step taken to mitigate the damage. On appeal to the High Court, ${ }^{87}$ Popplewell J disagreed, but, after being reversed by the Court of Appeal, ${ }^{88}$ his Lordship's decision was reinstated and his reasoning endorsed by the Supreme Court.

84 At [143] per Waller LJ.

85 Menelaou v Bank of Cyprus Plc [2015] UKSC 66, [2016] AC 176.

86 At [99] per Lord Neuberger, with whom Lord Clarke, Lord Kerr and Lord Wilson agreed. See also Andrews $v$ Australia and New Zealand Banking Group Ltd [2012] HCA 30, (2012) 247 CLR 205 at [13] (to hold that the doctrine of penalties is confined to obligations triggered by a breach of contract "would elevate form over substance", but compare Cavendish Square Holding BV v Makdessi, above n 4, at [42]); Homburg Houtimport BV v Agrosin Private Ltd (The Starsin) [2003] UKHL 12, [2004] 1 AC 715 at [34]; Breakspear v Ackland [2008] EWHC 220 (Ch), [2009] Ch 32 at [124]; Standard Life Assurance Ltd v Oak Dedicated Ltd [2008] EWHC 222 (Comm), [2008] 1 CLC 59 at [92]; Mauritius Commercial Bank Ltd v Hestia Holdings Ltd [2013] EWHC 1328 (Comm), [2013] 2 Lloyd's Rep 121 at [19]; Novoship (UK) Ltd v Mikhaylyuk [2014] EWCA Civ 908, [2015] QB 499 at [92]; and Super-Max Offshore Holdings v Malhotra [2017] EWHC 3246 (Comm) at [59] and [134].

87 Fulton Shipping Inc of Panama v Globalia Business Travel SAU of Spain [2014] EWHC 1547 (Comm), [2014] 2 Lloyd's Rep 230 [The New Flamenco (HC)].

88 The New Flamenco (CA), above n 73, per Longmore, Christopher Clarke and Sales LJJ. 
The Court of Appeal's decision in favour of the charterers turned on the fact that there was no available market for a substitute charter at the time of the repudiation. If a substitute charter had been available, the so-called market rule would have applied and the correct measure of damages would have been the difference between the contract and substitute market rates of hire, regardless of the fact that the owners did not actually go into the market. ${ }^{89}$ In such a situation, subsequent gains or losses resulting from the choice not to seek substitute hire are for the claimant's own account. They are the result of an independent decision not arising out of the breach. However, since there was no available market, ordinary principles of mitigation applied and therefore the question was whether the sale of the ship arose out of the consequences of the breach and in the ordinary course of business. The answer to that question was yes. By selling the ship and obtaining a price much higher than the value it would have had if the charter had remained on foot, the owners had made a considerable profit that arose from the consequences of the breach and should therefore be brought into account.

However, the Supreme Court, in a judgment delivered by Lord Clarke, ${ }^{90}$ disagreed. The owners were not required to bring into account the benefit derived from the sale because that benefit was not caused by the breach and neither was it the result of "an act of successful mitigation". ${ }^{91}$ The fall in the value of the ship was "irrelevant because the owners' interest in the capital value of the vessel had nothing to do with the interest injured by the charterers' repudiation", 92 namely, the loss of income from the remaining two years of the charter. The charterers' repudiation was not the legal cause of the sale because the ship could have been sold at any time, even while the charter remained on foot. Accordingly, when the owners did decide to sell, they were ${ }^{93}$

making a commercial decision at their own risk about the disposal of an interest in the vessel which was

no part of the subject matter of the charterparty and had nothing to do with the charterers.

Surprisingly, it was also held that the position was the same regardless of whether or not at the time of the repudiation a substitute two-year time charter, shorter charters, or even no work at all, had been available in the market. This is an important respect in which, unfortunately, the facts were unclear. As discussed in more detail elsewhere, ${ }^{94}$ in the first two situations the refusal to take account of the sale is readily justifiable on the basis that the existence of alternative charters would have enabled the owners to restore as nearly as possible the same position that they would have been in if the contract had not been breached, so that their choice not to do so would have constituted an

89 Koch Marine Inc v D'Amica Societa di Navigazione ARL (The Elena D'Amico) [1980] 1 Lloyd's Rep 75.

90 With whom Lord Neuberger, Lord Mance, Lord Sumption and Lord Hodge agreed.

91 The New Flamenco (SC), above n 63, at [34].

92 At [29].

93 At [32].

94 D McLauchlan and A Summers "Mitigation and Causation of Benefits" [2018] LMCLQ 171. 
independent decision for which they were responsible, for better or worse. Hence it would have been the exercise of this choice, not the charterers' repudiation, that was the legal cause of the ensuing financial consequences that turned out to be beneficial. ${ }^{95}$ However, it is difficult to accept that the charterers' repudiation would not have been the legal cause of the benefit derived from the sale if there was no work available for the ship at the time the contract was terminated. In this situation, the reality is that the owners would have had no choice other than to sell the ship and therefore, as the arbitrator and the Court of Appeal concluded, the benefit obtained from the sale was legally caused by the breach.

In holding that, irrespective of the state of the market, the sale was not caused by the breach and could not be regarded as a relevant act of mitigation, it seems that the decisive factor for the Supreme Court was that the ship was a capital asset that could have been sold at any time, including while the charter remained on foot. As a result, the sale "was incapable of mitigating the loss of the income stream". ${ }^{96}$ In my view, this is a formalistic distinction that should have had little bearing on the question whether the financial consequences of the owners' conduct in response to the breach ought, in principle, to be brought into account in assessing their damages. It fails to address the correct question. That question was not whether the owners had a choice whether or not to realise the capital value of the ship at any time, but whether, in the circumstances they faced at the time of the termination of the charter, they had a choice to put themselves, as nearly as possible, in the position they would have occupied if the contract had been performed. In other words, did they have a choice whether or not to restore their non-breach position? And, if the true position was that there was no work available for the ship, so that the sale was a practical necessity, no such choice existed and the resulting benefit ought to be brought into account.

This is not to say that the case was wrongly decided because, as mentioned above, the facts were unclear. If, for example, shorter charters had been available, the refusal to take account of the sale would be readily justifiable on the basis that the existence of alternative charters would have enabled the owners to restore as nearly as possible the same position that they would have been in if the contract had not been breached. In that event, their choice not to do so would have constituted an independent decision for which they were responsible, for better or worse. Hence it would have been

95 As Andrew Summers and I have argued (above n 94, at 180), the existence of an available market should not be dependent on whether there was a substitute two-year charter, so that only in that situation would the benefit from sale of the ship be caused, not by the breach, but by the owners' independent decision not to take advantage of the market. The underlying question must always be: what steps would restore the claimants $a s$ nearly as possible to the position that they would have been in but for the breach? In determining whether shipowners are engaged in speculation following a repudiated charter, the question should be, not whether there was an available market for a perfect substitute, but whether the owners made a choice not to avail themselves of the closest substitute that was available.

96 At [34]. 
the exercise of this choice, not the charterers' repudiation, that was the legal cause of the ensuing financial consequences that turned out to be beneficial.

However, it is perhaps reasonable to suggest that the true explanation for the Supreme Court's decision is that it was thought to be unjust that the charterers should be able to escape liability on the basis of what, as it transpired, was a beneficial sale by the owners of their capital asset. Early in his judgment Lord Clarke had quoted extensively from the reasoning of Popplewell J, including a passage in which he said that the ruling in favour of the owners could be justified on policy grounds. In that passage ${ }^{97}$ the Judge said that it would be "unjust and unfair" to allow the charterers to appropriate to themselves the fruits of the owners' original decision to invest in the vessel. When that decision was made they "[took] upon themselves the risk of fluctuations in its capital value ... and of the financial consequences of a decision as to whether or when to sell", and the charterers should not be allowed to take advantage of what turned out to be a beneficial sale as a basis for denying that loss resulted from their wrongful repudiation. Based on my informal discussions with private law scholars, there are many who agree with that point of view. They argue that the just response was to treat the sale of the ship as a matter for the owners' account and risk so that the capital benefit derived should not be regarded as a relevant compensating advantage that had the effect of extinguishing their damages claim. As Popplewell J pointed out in the passage quoted by Lord Clarke, the benefit was essentially no different than the proceeds of an insurance policy paid for by the claimant. Indeed, it is by no means certain that, if the contract had been performed, the ship would have been sold upon the expiry of the charter period: the owners might have judged that a rise in the charter market, and consequently an increase in the value of the ship, would soon occur. By contrast, others are firmly of the view that the benefit should be brought into account because the sale was a reasonable step taken to mitigate the damage arising from the charterers' repudiation which, due to the fall in the charter market, resulted in the owners being more than USD16m better off than if the contract had remained on foot. Accordingly, applying the fundamental compensatory principle, they suffered no loss and therefore they should recover nominal damages only. They argue, as I would, that this was the correct decision in principle, at least if the sale of the ship truly was a necessity.

\section{CONCLUSION}

Despite it being universally accepted as the fundamental principle governing damages awards for breach of civil obligations, application of the compensatory principle in practice is often far from straightforward. ${ }^{98}$ The law is far more complex than the frequent ritual incantations of the principle suggest. This is particularly so in relation to the circumstances in which post-breach external events that might appear to reduce or eliminate the loss claimed, or subsequent actions to like effect by the

97 The New Flamenco (HC), above n 87, at [73], quoted by Lord Clarke at [23].

98 As Gageler J observed in Lewis v Australian Capital Territory [2020] HCA 26, (2020) 381 ALR 375 at [32], although "[e]asily stated, the compensatory principle is not always easily applied". 
claimant, are to be brought into account. The modern cases discussed in this article concerning that and other questions have provoked much judicial disagreement and differences of opinion among academic commentators and, for the reasons I have given, the outcome in most of these cases either could or should have been different. Nearly all of them involved dissenting judgments at one or more stages of the proceedings. Perhaps the least contentious, in the light of the paucity of academic criticism, is the decision in Swynson, yet, as discussed, the outcome is not beyond question. It is perhaps also worth pointing out that two of the three eminent judges in the lower courts (Rose $\mathrm{J}$ and Sales $\mathrm{LJ}^{99}$ ) who had no apparent qualms about upholding the damages claim have since been promoted to the Supreme Court. And, as for The New Flamenco, the judgment of the Court delivered by Lord Clarke is a major disappointment because, after reciting the facts and the lower courts' reasoning, it contains a mere seven paragraphs of original analysis, much of which is incomplete or opaque, and no citation of authority apart from the cases referred to in reciting the lower courts' reasoning.

A curious feature of the above two cases is that, although they were heard together, the decision in The New Flamenco was handed down nearly three months after that in Swynson. ${ }^{100}$ This seems surprising at first sight because the latter raised other, on the surface more difficult, issues than the one I have discussed. The claimants sought to uphold the award on a number of alternative bases ${ }^{101}$ and three full judgments making much the same points and running to a total of 121 paragraphs were delivered. By contrast, in The New Flamenco, there was essentially one issue only and, as mentioned above, the case was resolved by a single, relatively brief, judgment delivered by Lord Clarke. It might therefore have been expected that the decisions would be handed down at least contemporaneously. It is, of course, dangerous to speculate on the reasons why this did not occur. One simple explanation is that in Swynson their Lordships regarded the correct outcome as relatively straightforward and that three of them preferred to write their own judgments, whereas in The New Flamenco the issue was initially seen as more difficult and requiring further deliberation, although eventually a consensus was reached which it was thought did not need a lengthy explanation or analysis of the authorities. Another explanation is that the judges in The New Flamenco were in fact deeply divided, not so much as to whether to allow the appeal but rather as to the grounds for doing so, and that, for one reason or another, when it was felt that delivery of judgment could be delayed no longer, it was decided that the case could be disposed of satisfactorily in a single and "economically" reasoned judgment which Lord Clarke agreed to prepare. Having watched the whole of argument online, I am inclined to think that the latter explanation may not be too wide of the mark, but naturally we will never know.

99 Now Lady Rose of Colmworth and Lord Sales. The latter was also a member of the Court of Appeal majority in The New Flamenco.

100 The judgment in Swynson was handed down on 11 April 2017. The judgment in The New Flamenco was handed down on 28 June 2017.

101 These included the principle of "transferred loss", unjust enrichment and equitable subrogation. 
That speculation aside, The New Flamenco can now be added to the list of cases where claimants have recovered compensatory damages greater than their factual loss apparent at the date of trial. By ignoring the actual sale, the award of damages left the owners in a better position than if the breach had not occurred. The Supreme Court's decision thus lends credence to Popplewell J's remark in the High Court that: ${ }^{102}$

[t]he answer to the question whether a claimant is bound to bring a benefit into account in calculating his damages is not to be found in a simple application of the compensatory principle.

102 The New Flamenco (HC), above n 87, at [17], quoted by Lord Clarke at [23]. 
(2021) 52 VUWLR 